ZOOLOGIA 27 (3): 372-376, June, 2010

doi: $10.1590 /$ S1984-46702010000300008

\title{
Seasonal variations in scorpion activities (Arachnida: Scorpiones) in an area of Caatinga vegetation in northeastern Brazil
}

\author{
Cristiane S. Araújo'; Denise M. Candido²; Helder F. P. de Araújo3; \\ Sidclay C. Dias ${ }^{4} \&$ Alexandre Vasconcellos ${ }^{1}$
}

\author{
${ }^{1}$ Laboratório de Ecologia e Conservação da Biodiversidade, Departamento de Botânica, Ecologia e Zoologia, Universidade \\ Federal do Rio Grande do Norte. 59072-970 Natal, Rio Grande do Norte, Brazil. \\ E-mail: crisecologa@yahoo.com.br; avasconcellos@cb.ufrn.br \\ 2 Laboratório de Artrópodes, Instituto Butantan. Avenida Vital Brasil 1500, 05503-900 São Paulo, São Paulo, Brazil. \\ E-mail: denisecandido@butantan.gov.br \\ ${ }^{3}$ Departamento de Ciências Biológicas, Universidade Federal da Paraíba. 58397-000 Areia, Paraíba, Brazil. \\ E-mail: hfparaujo@yahoo.com.br \\ ${ }^{4}$ Laboratório de Aracnologia, Museu Paraense Emílio Goeldi. Avenida Perimetral 1901, Caixa postal 399, 66017-970 Belém, \\ Pará, Brazil. E-mail: pachistopelma@hotmail.com
}

\begin{abstract}
Seasonal variations in scorpion activity were investigated during a 24 month period in an area of Caatinga (dryland) vegetation in the state of Paraíba, Brazil. The total number of scorpions captured was correlated with climatic variables and prey abundance. Scorpions were captured monthly using pitfall traps; their potential prey was captured using malaise, beating trays and pitfalls. A total of 104 scorpions were captured, representing four species: the bothriurids Bothriurus asper (Pocock, 1893) $(n=74 ; 71.2 \%)$ and B. rochai (Mello-Leitão, 1932) $(n=20 ; 19.2 \%)$, and the buthids Rhopalurus rochai (Borelli, 1910) $(n=4 ; 3.8 \%)$ and Tityus stigmurus (Thorell, 1876$)(n=1 ; 1.0 \%)$. The sex ratios (male:female) of the two most abundant species were 14:1 for $B$. asper and 7:1 for B. rochai. The abundance of scorpions captured was significantly correlated with precipitation, real evapotranspiration, and abundance of invertebrates (mainly insects). Scorpion activities, especially those of B. asper and B. rochai, may be closely related to their reproductive cycles. Reproduction apparently reaches its maximum when there is an abundance of food, which in the Caatinga is strongly associated with rainfall patterns.
\end{abstract}

KEY WORDS. Environmental factors; Neotropical region; reproduction; semi-arid; seasonality.

Scorpions are common and ecologically important arthropods in arid and semi-arid ecosystems throughout the world (Brown 2004, Polis 2001). They are one of the most important predators in arid region communities in terms of density, biomass and diversity (Polis 1990); moreover, scorpions exert predatory pressure on a wide variety of insect and spider populations, having an impact in the flow of energy of these ecosystems (McCormick \& Polis 1990). Many environmental factors can influence the taxocenoses of scorpions in arid region ecosystems, such as the type of soil, topography, hydrology, food resources, and especially, temperature and precipitation (PoLIs 1990, Dias et al. 2006, Yamaguti \& Pinto-Da-Rocha 2006).

The caatinga occupies an area of about $800,000 \mathrm{~km}^{2}$ (corresponding to ca. $10 \%$ of the Brazilian territory) in the northeastern region of Brazil (Silva et al. 2004, Fiaschi \& Pirani 2009). The prevailing semiarid climate, with a high evapotranspiration potential (1500-2000 mm/year) and low precipitation (300-1000 $\mathrm{mm} /$ year) concentrated in a short period of 3-5 months (SAMPAIO
1995), is characterized by marked seasonality, making the caatinga an important natural laboratory for scientific studies (LeAL et al. 2005). The vegetation forms a landscape mosaic that varies from open thorny scrub to low dry forests, and is partly determined by the rainfall gradient characteristic of this ecosystem.

In the present study, we investigated the seasonal variations in scorpion activity on the soil surface of an area of caatinga in the State of Paraiba, Brazil, during a period of 24 months. Additionally, we have analyzed the correlation between the number of scorpions captured during each month with climatic variables and availability of potential prey.

\section{MATERIAL AND METHODS}

The study area was located at the Fazenda Almas Private Natural Reserve (RPPN-Fazenda Alma, $7^{\circ} 28^{\prime} \mathrm{S}, 36^{\circ} 52^{\prime} \mathrm{W}$ ), an area of 3,505 ha in the municipalities of São José dos Cordeiros and Sumé, state of Paraíba, northeastern Brazil (Moura et al. 2006). 
The local vegetation varies from a dense to a somewhat open arboreal caatinga formation, with scattered areas of exposed rocks and their characteristic dryland flora (ВАRвоsA et al. 2007).

Rainfall data were obtained from the Agência Executiva de Gestão das Águas do Estado de Paraíba (2008), and data relative to the real evapotranspiration, as well as water deficit and water excess, were obtained from the Centro de Previsão de Tempo E Estudos Climáticos (2008), municipality of Sumé. We measured the temperature and relative humidity data directly at the sampling localities with the help of a digital thermo-hygrometer (an average of six days of reading per month, with five readings per day, taken between 05:00 a.m. and 12:00 p.m.).

The study area was delimited by a 100 ha grid near the center of the largest forest fragment in the RPPN-Fazenda Almas, with six parallel transects (A, B, C, D, E, F) separated from one another by $200 \mathrm{~m}$. Six sampling points (1, 2, 3, 4, 5 and 6), separated from one another by $200 \mathrm{~m}$, were placed in each transect line, forming a $6 \times 6$ matrix with a total of 36 sampling points. Samples were taken monthly during 24 months, between December/2006 and November/2008. Each month, only one point in each transect was sampled, and the same point was sampled only twice a year, once in each season.

Invertebrate sampling was conducted with malaise traps (surface of $2 \mathrm{~m}^{2}$ ), pitfall traps $(15 \mathrm{~cm}$ diameter at the ground level and $10 \mathrm{~cm}$ deep) and beating trays. Six malaise traps were left in the field during one day every month. Five pitfall traps were placed in each sampling point and were arranged in a crossshaped pattern, with one in the center and four at the tip of each cross, distant $1 \mathrm{~m}$ from one another. Pitfalls were connected by a plastic device $15 \mathrm{~cm}$ high, which increased the sampling area to $4 \mathrm{~m}^{2}$. These traps were maintained for three days and their contents were pooled into a single sample. In each sampling point, four trees were sampled by beating the branches onto trays and all invertebrates collected were pooled into one sample.

All samples were studied at the Laboratório de Ecologia e Conservação da Biodiversidade (LECOB) of the Universidade Federal do Rio Grande do Norte, where the invertebrates were separated by taxonomic order, counted, and conserved in $75 \%$ ethanol. The scorpions were identified to species and stored in the Coleção de Aracnídeos do Laboratório de Artrópodes do Instituto Butantan, São Paulo, Brazil (numbers 5269 to 5319).

Correlation analyses (using the Spearman correlation) were performed between the number of scorpions collected each month and the following values, obtained for the sampling month, and for the month preceding the sampling date: total monthly precipitation $(\mathrm{mm})$, monthly temperature averages $\left({ }^{\circ} \mathrm{C}\right)$, relative humidity (\%), real evapotranspiration ( $\mathrm{mm})$, and water deficit. Scorpion abundance was also compared with the abundance of all arthropods collected in the three types of traps, particularly insects and spiders, the main prey of scorpions (PoLIs 1990). Small arthropods ( $<2 \mathrm{~mm}$ ) such as Acari, Collembola, Siphonaptera, Thysanoptera, and Psocoptera were excluded from the analyses. Since the families of spiders captured by pitfall traps generally differ from those obtained by beating the vegetation, we have chosen to present the analyses for "spiders pitfall", and "spiders other methods" separately. All analyses were performed using the Statistica software for Windows (6.0). The chi-square test was used to analyze the sex-ratios of the most abundant species.

\section{RESULTS}

Four species and 104 individual scorpions belonging to Bothriuridae and Buthidae were captured during the 24 months of sampling. The following species were present in our samples: Bothriuridae: Bothriurus asper (Pocock, 1893) ( $\mathrm{n}=74 ; 71.2 \%$ ) and B. rochai (Mello-Leitão, 1932) ( $\mathrm{n}=20 ; 19.2 \%)$; Buthidae: Rhopalurus rochai (Borelli, 1910) ( $\mathrm{n}=4 ; 3.8 \%)$ and Tityus stigmurus (Thorell, 1876) $(\mathrm{n}=1 ; 1.0 \%)$. Five immature individuals could not be identified.

Considering all scorpions collected, the frequency of each sex ratio was as follows: $68 \%$ males, $9 \%$ females, and $23 \%$ juveniles. Among the individuals of $B$. asper captured, $77 \%$ were males, $5.4 \%$ were females, and $17.6 \%$ were juveniles, what resulted in a sex ratio of $14: 1\left(\chi^{2}=46.05\right.$, d.f. $\left.=1, \mathrm{p}<0.01\right)$. For $B$. rochai, these proportions were $65 \%$ males, $10 \%$ females and $25 \%$ juveniles, with a sex ratio of 7:1 $\left(\chi^{2}=8.07\right.$, d.f. $=1$, p $\left.<0.01\right)$.

About $84 \%$ of the scorpions were collected during the rainy months. Precipitation (Fig. 1) and real evapotranspiration rates in the month of sampling were the climatic variables most strongly correlated with the number of scorpions collected (Tab. I). When analyzed individually, B. rochai and B. asper showed a similar seasonal pattern of abundance (Figs 2 and 3 ).

Scorpion abundance was significantly correlated with the abundance of arthropods $\left(\mathrm{r}_{\mathrm{s}}=0.52, \mathrm{p}<0.05\right)$, the abundance of insects $\left(r_{s}=0.47, p<0.05\right)$, and the abundance of spiders collected in the pitfall traps $\left(\mathrm{r}_{\mathrm{s}}=0.61, \mathrm{p}<0.05\right)$. When all spiders collected were considered collectively, however, scorpion abundance did not correlate with total spider abundance $\left(\mathrm{r}_{\mathrm{s}}=\right.$ $0.15, \mathrm{p}>0.05)$. Scorpion abundance was also significantly correlated with both the abundance of arthropods collected using beating trays $\left(r_{s}=0.44, p<0.05\right)$ and collected in pitfall traps $\left(r_{s}=0.43, p<0.05\right)$, but not with the abundance of arthropods collected in Malaise traps $\left(r_{s}=0.26, p>0.05\right)$.

\section{DISCUSSION}

In the present study, the abundance of scorpions captured on the soil surface may be largely explained by the foraging habits and/or the reproductive behavior of each species. As a rule, scorpions are sedentary animals that spend up to $97 \%$ of their lives inside their burrows (Polis 1990). Despite some differences between various groups, for instance between bothriurids and buthids (LOURENÇO 2002), scorpions generally display a sit-andwait foraging strategy (McCormick \& Polis 1990). During their mating period, however, males undergo marked behavioral changes, decreasing their foraging activity and covering long distances looking for females (Polis \& Farley 1979). 

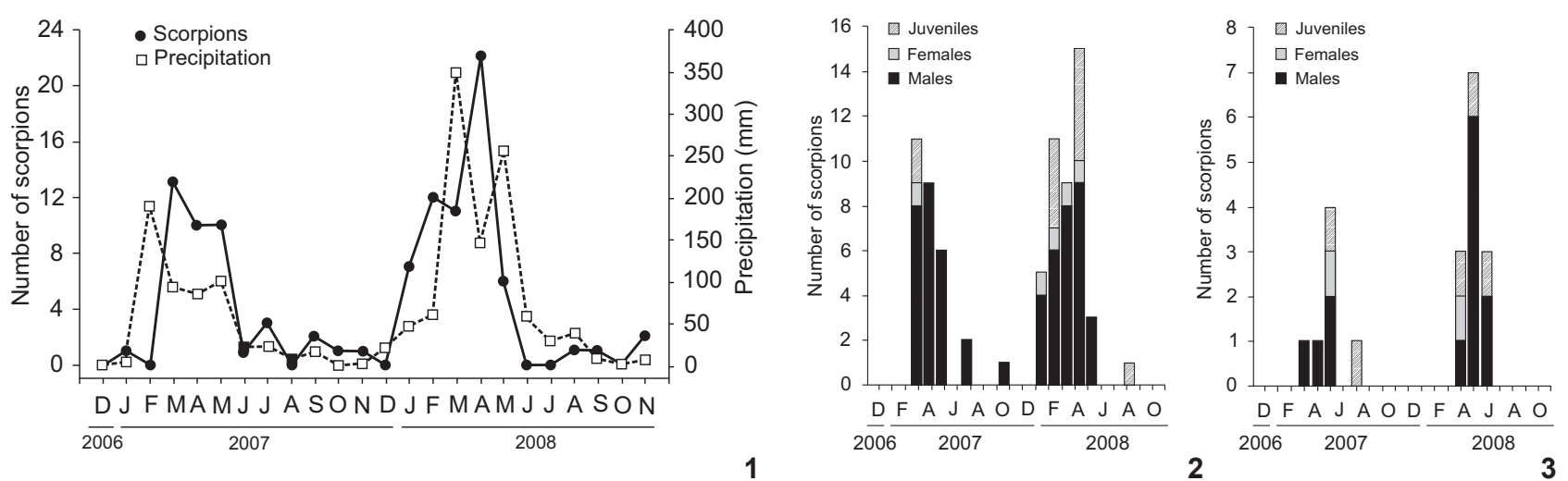

Figures 1-3. Fluctuations in precipitation and the absolute abundance of scorpions from December/2006 to November/2008 at the Fazenda Almas Private Natural Reserve, Paraíba State, Brazil (1); Fluctuations in the abundance of male, female and juveniles of B. asper (2) and B. rochai (3).

Table I. Results of the Spearman analysis of the absolute abundance of scorpions with climatic variables during each sampling month, as well as with the previous month (indicated with " $\left.(-1)^{\prime \prime}\right)$.

\begin{tabular}{lccc}
\hline \multicolumn{1}{c}{ Climatic Variables } & B. asper & B. rochai & All species \\
\hline Precipitation $(\mathrm{mm})$ & $0.64^{*}$ & $0.60^{*}$ & $0.54^{*}$ \\
Precipitation $(\mathrm{mm}){ }^{(-1)}$ & $0.57^{*}$ & $0.49^{*}$ & $0.45^{*}$ \\
Temperature $\left({ }^{\circ} \mathrm{C}\right)$ & 0.29 & 0.13 & 0.24 \\
Temperature $\left({ }^{\circ} \mathrm{C}\right){ }^{(-1)}$ & $0.49^{*}$ & 0.27 & $0.47^{*}$ \\
Relative Humidity of the air (\%) & $0.54^{*}$ & $0.48^{*}$ & 0.39 \\
Relative Humidity of the air $(\%))^{(-1)}$ & 0.37 & $0.51^{*}$ & 0.27 \\
Water deficit & 0.34 & 0.29 & 0.40 \\
Water deficit $(-1)$ & 0.38 & 0.35 & 0.25 \\
Real evapotranspiration $(\mathrm{mm})$ & $0.61^{*}$ & $0.60^{*}$ & $0.52^{*}$ \\
Real evapotranspiration $(\mathrm{mm})(-1)$ & $0.44^{*}$ & $0.44^{*}$ & 0.31
\end{tabular}

* Indicates $p \leqslant 0.05$.

The higher capture rate of buthriurids ( $90 \%$ of the total) with respect to buthids in our data is most likely a reflection of their different habits rather than their relative abundance in the study area. Buthriurid scorpions are fossorial, what makes them more susceptible to falling in pitfall traps when compared with the primarily arboreal buthids.

Most individuals were collected during the rainy months, and were almost exclusively males; most likely, this period of high activity corresponds to the mating season, as observed by PINTO-DA-Rocha et al. (2007). Scorpions normally live and hunt around the openings of their burrows, and are normally not captured in pitfall traps due to their low activity and movement rates (Lourenço \& Cuellar 1995, PinTo-Da-Rocha et al. 2007). During the mating season, however, males actively seek out females, which increase their probability of falling in pitfall traps.

A previous study has linked the incidence of scorpion bites in Colima, a Mexican State located on the Pacific West coast, with temperature and precipitation, following the strong seasonal pattern of that region (CHOwELl et al. 2005). Likewise, the largest numbers of accidents with scorpions in southeastern Brazil occur during the warm and rainy months (SOAREs et al. 2002). These observations suggest that scorpions boost their above-ground activities during hot and rainy periods, which increases their chances to encounter humans.

The highly seasonal nature of the caatinga is almost certainly a determining factor for above-ground scorpion activity (foraging and/or reproduction) due to the marked influence rainfall and temperature patterns exert on that ecosystem. This contrasts with the situation found for the bothriurid Thestylus aurantiurus Yamaguti \& Pinto-da-Rocha, 2003 in the Atlantic Forest. Even though the reproductive period of the species occurs during the warm and rainy season, individual abundance is not significantly correlated with temperature or precipitation (Yamaguti \& PinTo-DA-Rocha 2006). One explanation for 
the latter may be the low seasonality of and constantly humid environment of the Atlantic Forest.

The beginning of the rainy season in arid and semi-arid ecosystems provides favorable environmental conditions for the development of many organisms, including insects. The increase in reproductive activity and abundance of many groups of insects during the rainy season is correlated with renewed plant growth, acceleration in the decomposition of the leaf litter accumulated during the dry season, and with the movement of insects that are constrained to humid sites during the dry season (WOLDA 1988, WHITFORD 1996).

The abundance of arthropods (mainly insects) in our data was correlated with the abundance of scorpions on the soil surface. An increase in foraging activity occurs during the rainy season when prey becomes widely available in the caatinga. Our results agree with those obtained by PoLIs (1980), who also noted that scorpion density in arid environments is highly correlated with the abundance of insects on the soil surface.

The apparent inactivity of scorpions during the dry season can be understood in terms of scarcity of prey during that period. The ability to consume large quantities of food in a single meal and to store energy efficiently, combined with a low metabolic rate, allows scorpions to survive without ingesting any prey for long periods of time (McCormick \& Polis 1990). Even though some species of scorpions are known to store prey within their burrows (McCormick \& Polis 1990), this phenomenon is not presently known for neotropical buthids or bothriurids.

An increase in food resources in the caatinga during the rainy season appears to be a key factor triggering the reproductive activities of $B$. asper and $B$. rochai. Reproduction during the rainy season also tends to maximize the birth and survival rates of the offspring, as both growth and reproduction in scorpions are directly affected by the availability of food (PoLIs 1990).

In conclusion, marked seasonal variations in aboveground scorpion activity were observed in the caatinga area studied by us. This foraging and/or reproductive activity was closely associated with rainfall regimes and their direct and indirect effects on the availability of prey, especially insects.

\section{ACKNOWLEDGEMENTS}

The authors would like to thank Eunice Braz, owner of the RPPN Fazenda Almas, for logistic support during our field work, and CNPq (PELD-Caatinga) for financial support.

\section{LITERATURE CITED}

Agência Executiva de Gestão das Águas do Estado da Paraíba. 2008. Available online at: http://www2.aesa.pb.gov.br/meteoro/ pcdlmrs.shtml [Accessed: 15/XII/2008].

Barbosa, M.R.V.; I.B. Lima; J.R. Lima; J.P. Cunha; M.F. Agra \& W.W. Thomas. 2007. Vegetação e flora no Cariri Paraibano. Oecologia Brasiliensis 11 (3): 313-322.

Brown, C.A. 2004. Life histories of four species of scorpion in three families (Buthidae, Diplocentridae, Vaejovidae) from Arizona and New Mexico. Journal of Arachnology 32: 193207.

Centro de Previsão de Tempo e Estudos Climáticos. 2008. Programa de Monitoramento Climático em Tempo Real da Região Nordeste. Available online at: http://www.cptec.inpe.br/ proclima [Accessed:15/XII/2008].

Chowell G.; J.M. Hyman; P. Diaz-Duenas \& N.W. Hengartner. 2005. Predicting scorpion sting incidence in an endemic region using climatological variables. International Journal of Environmental Health Research 15 (6): 425-435.

Dias, S.C.; D.M. Candido \& A.D. Brescovit. 2006. Scorpions from Mata do Buraquinho, João Pessoa, Paraíba, Brazil, with ecological notes on a population of Ananteris mauryi Lourenço (Scorpiones, Buthidae). Revista Brasileira de Zoologia 23 (1): 707-710.

Fiaschi, P. \& J.R. Pirani. 2009. Review of plant biogeographic studies in Brazil. Journal of Systematics and Evolution 47 (5): 477-496.

Leal, I.R.; J.M.C. Silva; M. Tabarelli, \& T. Lacher Jr. 2005. Mudando o curso da conservação da biodiversidade na Caatinga do Nordeste do Brasil. Megadiversidade 1 (1): 139-146.

Lourenço, W.R. 2002. Scorpions of Brazil. Paris, Les Editions de l'If, 308p.

Lourenço, W.R. \& O. Cuellar. 1995. Scorpions, scorpionism, life history strategies and parthenogenesis. Journal of Venomous Animals and Toxins 1 (2): 50-64.

McCormick, S.J. \& G.A. Polis. 1990. Prey, predators and parasites, p. 294-320. In: G.A. PolIs (Ed.). The biology of scorpions. Stanford, Stanford University Press, 587p.

Moura, F.M.S.; A. Vasconcellos; V.F.P. Araújo \& A.G. BandeiRA.2006. Seasonality in foraging behaviour of Constrictotermes cyphergaster (Termitidae, Nasutitermitinae) in the Caatinga of northeastern Brazil. Insectes Sociaux 53 (4): 472-479.

Pinto-Da-Rocha, R.; C. Araujo; J.A.P. Barreiros \& A. Bonaldo. 2007. Arthropoda, Arachnida, Scorpiones: Estação Científica Ferreira Penna and Juriti Plateau, Pará, Brazil. Check List (UNESP) 3: 145-147.

PolIs, G.A. 1980. Seasonal patterns and age-specific variation in the surface activity of a population of desert scorpions in relation to environmental factors. Journal of Animal Ecology 49 (1): 1-18.

Polis, G.A. 1990. Ecology, p. 247-293. In: G.A. Polis (Ed.). The biology of scorpions. Stanford, Stanford University Press, $587 \mathrm{p}$.

Polis, G.A. 2001. Population and community ecology of desert scorpions, p. 302-316. In: P.H. Brownell \& G.A. Polis (Eds). Scorpion Biology and Research. Oxford, Oxford University Press, 595p.

Polis, G.A. \& R.D. FarLey. 1979. Behavior and ecology of mating in the cannibalistic scorpion, Paruroctonus mesaensis Stahnke (Scorpionida: Vaejovidae). Journal of Arachnology 7: 3346. 
SampaIo, E.V.S. B. 1995. Overview of the Brazilian caatinga, p. 35-63. In: S.H. Bullock; H.A. Mooney \& E. Medina (Eds). Seasonally dry tropical forests. New York, Cambridge University Press, 875p.

Silva, J.M.C.; M. Tabarelli; M.T. Fonseca \& L.V. Lins. 2004. Biodiversidade da Caatinga: áreas prioritárias para conservação. Brasília, Ministério do Meio Ambiente, 382p.

Soares, M.R.M.; C.S. Azevedo \& M. Maria. 2002. Escorpionismo em Belo Horizonte, MG: um estudo retrospectivo. Revista da Sociedade Brasileira de Medicina Tropical 35 (4): 359-
363.

WHITFORD, W.G. 1996. The importance of the biodiversity of soil biota in arid ecosystems. Biodiversity and Conservation 5: 185-195.

Wolda, H. 1988. Insect seasonality:Why? Annual Review of Ecology and Systematics 19: 1-18.

Yamaguti, H.Y. \& R. Pinto-Da-Rocha. 2006. Ecology of Thestylus aurantiurus of the Parque Estadual da Serra da Cantareira, São Paulo, Brazil (Scorpiones, Bothriuridae). Journal of Arachnology 34: 214-220.

Submitted: 10.X.2009; Accepted: 10.IV.2010.

Editorial responsibility: Pedro Gnaspini 